\title{
PENGARUH GAYA KEPEMIMPINAN TRANSFORMASIONAL DAN KOMPENSASI TERHADAP KINERJA KARYAWAN DENGAN MOTIVASI SEBAGAI VARIABEL INTERVENING
}

\author{
Wahyu Budi Priyanto \\ PT. BO KYUNG Pasuruan \\ E-mail: yoe.minhoo@gmail.com
}

\begin{abstract}
Compensation is also self motivation factor for employees, where those things end in high-low level of work result or performance. This research purposes to test the effect of transformational leadership style, compensation, and motivation of employee's performance, motivation as an effect mediator from transformational leadership style and compensation to employee's performance in PT. Bo Kyung Pasuruan. This research is explanatory. In this research uses 96 samples from 2719 employees that work in PT. Bo Kyung Pasuruan. The result of Partial Least Square $(P L S)$ this research shows that transformational leadership style is positively effected but not significant to motivation and employee's performance. Motivation affect transformational leadership style of employee's performance, and motivation does not influence compensation of employee's performance in PT. Bo Kyung Pasuruan.
\end{abstract}

Keywords: Compensation, Employees Performance, Motivation, Transformational Leadership.

\begin{abstract}
Abstrak
Kompensasi juga merupakan faktor yang menjadi motivasi tersendiri bagi karyawan di suatu perusahaan, dimana hal-hal tersebut berujung pada tingkat tinggi rendahnya hasil kerja/kinerja. Penelitian ini bertujuan untuk menguji pengaruh gaya kepemimpinan transformasional, kompensasi dan motivasi terhadap kinerja karyawan, motivasi sebagai mediator pengaruh dari gaya kepemimpinan transformasional dan kompensasi terhadap kinerja karyawan pada PT. Bo Kyung Pasuruan. Penelitian ini bersifat eksplanatori. Pada penelitian ini menggunakan sampel sebanyak 96 responden dari populasi berjumlah 2719 karyawan yang bekerja pada PT. Bo Kyung Pasuruan. Hasil analisis Partial Least Square (PLS) penelitian ini menunjukkan bahwa gaya kepemimpinan transfomasional berpengaruh positif tetapi tidak signifikan terhadap motivasi dan kinerja karyawan, kompensasi berpengaruh positif dan signifikan terhadap motivasi dan kinerja karyawan. Motivasi memediasi pengaruh gaya kepemimpinan transformasional terhadap kinerja karyawan, dan motivasi tidak memediasi pengaruh kompensasi terhadap kinerja karyawan pada PT. Bo kyung Pasuruan.
\end{abstract}

Kata Kunci: Gaya Kepemimpinan Transformasional, Kompensasi, Kinerja Karyawan, Motivasi. 
Salah satu unsur terpenting yang dapat mendukung jalannya perusahaan adalah sumber daya manusia (karyawan). Tenaga kerja atau sumber daya manusia dapat diartikan sebagai buruh, karyawan, pekerja atau pegawai yang memiliki keahlian dibidangnya masing-masing yang pada hakikatnya mempunyai maksud yang sama untuk mencapai suatu tujuan organisasi atau perusahaan. Dengan demikian maka manajemen sumber daya manusia mempunyai peran penting dalam menentukan keberhasilan suatu perusahaan.

Dalam hal pelaksanaan pekerjaan, peran pemimpin juga berpengaruh sangat dominan. Gaya kepemimpinan akan membawa dampak tersendiri dan berbedabeda dampaknya dalam setiap pelaksanaannya. Pemimpin memiliki kecenderungan memerintah dan menekan para karyawan, sehingga karyawan merasa tersudut dan merasa hanya sebagai objek yang dieksploitasi oleh para pemimpin. Gaya kepemimpinan terbagi menjadi gaya kepemimpinan transformasional dan gaya kepemimpinan transaksional menurut (Bass and Avolio, 1990). Gaya kepemimpinan transformasional memberikan edukasi dan transfer keahlian dari seorang pemimpin kepada karyawan, dimana dalam pelaksanaan gaya kepemimpinan transformasional seorang pemimpin cenderung memberi contoh dan melayani para karyawan. Seperti yang dikemukakan (Robbins and Judge, 2015) gaya kepemimpinan transformasional adalah pemimpin yang menginspirasi para pengikutnya untuk mengesampingkan kepentingan pribadi mereka demi kebaikan organisasi dan mereka mampu memiliki pengaruh yang luar biasa pada diri para pengikutnya.

Keberhasilan suatu organisasi sangat dipengaruhi oleh kinerja individu, berhasil atau tidaknya suatu organisasi tersebut dalam menjalankan tugas mereka. Setiap organisasi maupun perusahaan akan selalu berusaha untuk meningkatkan kinerja karyawan, dengan harapan apa yang menjadi tujuan perusahaan akan tercapai. Meningkat dan menurunnya kinerja karyawan secara langsung ataupun tidak dapat berpengaruh terhadap kinerja perusahaan secara keseluruhan. Faktor yang mempengaruhi kinerja karyawan seperti yang dikemukakan oleh (Suartama and Ardana, 2014) dalam penelitiannya, faktor-faktor yang mempengaruhi kinerja karyawan antara lain gaya kepemimpinan, kompensasi finansial, pendidikan, stress kerja dan disiplin kerja.

Menurut (Siagian, 2004) sistem kompensasi yang diberikan suatu organisasi dapat berbentuk finansial dan non finansial. (Odunlami and Matthew, 2014) Kompensasi didefinisikan sebagai total semua hadiah yang diberikan kepada karyawan sebagai imbalan atas pelayanan mereka, tujuan keseluruhan yang menarik, mempertahankan dan memotivasi karyawan. Kompensasi adalah output dan manfaat yang karyawan terima dalam bentuk gaji, upah dan imbalan untuk meningkatkan kinerja (Muhammad et al., 2014).

Selain dari faktor kepemimpinan dan kompensasi, faktor lain adalah motivasi yang diberikan kepada karyawan. Karyawan dapat melaksanakan tugasnya secara maksimal antara lain ditentukan oleh motivasi yang mendorong karyawan tersebut bekerja dengan tekun, serta disiplin sehingga tercapai tujuan perusahaan di bawah kepemimpinan yang dapat menciptakan suasana kerja yang kondusif. Setiap pegawai belum tentu bersedia mengerahkan kinerja yang dimilikinya secara optimal, sehingga masih diperlukan adanya pendorong agar seseorang dapat mengerahkan segala kemampuannya tersebut untuk bekerja. Daya dorongan tersebut adalah motivasi.

Gaya kepemimpinan mempengaruhi kinerja karyawan dengan sangat signifikan, sebagaimana dinyatakan dalam hasil penelitian (Mondiani, 2012), (Paracha et al., 2012), (Pradeep et al., 2011) dan (Sundi, 2013b). Begitu pula tentang kompensasi yang berpengaruh 
positif dan signifikan terhadap kinerja karyawan, sesuai dengan hasil penelitian (Odunlami and Matthew, 2014) dan (Ramzan et al., 2014). Sedangkan motivasi dinyatakan juga berpengaruh positif dan signifikan terhadap kinerja karyawan dalam hasil penelitian (Masood, 2013b). Fenomena yang terjadi dalam industri alas kaki PT. Bo Kyung Pasuruan adalah dengan adanya pergantian pemimpin dan perubahan kompensasi membawa dampak terhadap kinerja karyawan dan produktivitas perusahaan secara umum. Penelitian ini bertujuan untuk menguji model hubungan gaya kepemimpinan transformasional dan kompensasi terhadap kinerja karyawan, dengan motivasi sebagai variabel intervening.

\section{Metode Penelitian}

Metode penelitian ini akan digunakan untuk menjawab hipotesis penelitian sebagai berikut:

H1: Gaya kepemimpinan transformasional berpengaruh positif dan signifikan terhadap kinerja karyawan

$\mathrm{H} 2$ : Kompensasi berpengaruh positif dan signifikan terhadap kinerja karyawan

H3: Gaya kepemimpinan transformasional berpengaruh positif dan signifikan terhadap motivasi

H4: Kompensasi berpengaruh positif dan signifikan terhadap motivasi

H5: Motivasi berpengaruh positif dan signifikan terhadap kinerja karyawan

H6: Gaya kepemimpinan transformasional berpengaruh positif dan signifikan terhadap kinerja karyawan melalui motivasi

H7: Kompensasi berpengaruh positif dan signifikan terhadap kinerja karyawan melalui motivasi

Penelitian ini menggunakan jenis eksplanatori yang mendasarkan pada teori atau hipotesis untuk menguji suatu fenomena yang terjadi (Cooper and Schindler, 2003). Populasi dalam penelitian ini adalah semua karyawan yang bekerja pada PT. Bo Kyung Pasuruan. Dalam penelitian ini sampel digunakan adalah 96 responden. Penelitian ini menggunakan teknik pengambilan data dengan menyebarkan kuesioner secara langsung kepada responden. Daftar pertanyaan terkait dengan item-item variabel gaya kepemimpinan transformasional, kompe-nsasi, motivasi dan kinerja karyawan.

Adapun yang menjadi indikator dalam penelitian ini adalah: Pertama, Gaya Kepemimpinan Transformasional (X1) meliputi Inspirasional, Kharismatik, Stimulus intelektual, Perhatian individu. Kedua, Kompensasi (X2) meliputi Kebenaran dan keadilan, Biaya hidup, Insentif, dan Tunjangan. Ketiga, Motivasi (X3) meliputi Kebutuhan fisiologis, Kebutuhan akan keamanan, kebutuhan sosial, kebutuhan penghargaan dan kebutuhan untuk aktualisasi diri. Keempat, Kinerja karyawan (Y) meliputi Kualitas, Kuantitas, Pengetahuan dan Keterampilan, dan Ketepatan waktu.

\section{Hasil Penelitiian dan Pembahasan}

Hasil olah data dengan menggunakan alat bantu software SmartPLS, diperoleh hasil output dari model struktur konstruk loading factor yang akan menjelaskan antara konstruk gaya kepemimpinan transformasional, kompe-nsasi, motivasi dan kinerja karyawan yang tampak pada gambar 1 .

Dari tabel. 2 evaluasi model pengukuran AVE pengolahan data menunjukkan nilai AVE pada setiap variabel diatas 0,5 . Berdasarkan tabel 4.13 tampak nilai AVE pada variabel Gaya Kepemimpinan Transformasional sebesar 0.740, Kompensasi sebesar 0,546, Motivasi sebesar 0,625 dan Kinerja Karyawan sebesar 0,632. Dapat dikatakan bahwa secara disciminant validity, model pengukuran tersebut adalah baik.

Pada tabel.3 diatas koefisien determinasi (R-Square) yang didapatkan dari model variabel Gaya Kepemimpinan ransformasional, Kompensasi dan Motivasi terhadap Kinerja Karyawan sebesar 0,428 menyatakan bahwa Kinerja 
Karyawan mampu dijelaskan oleh variabel

Gaya

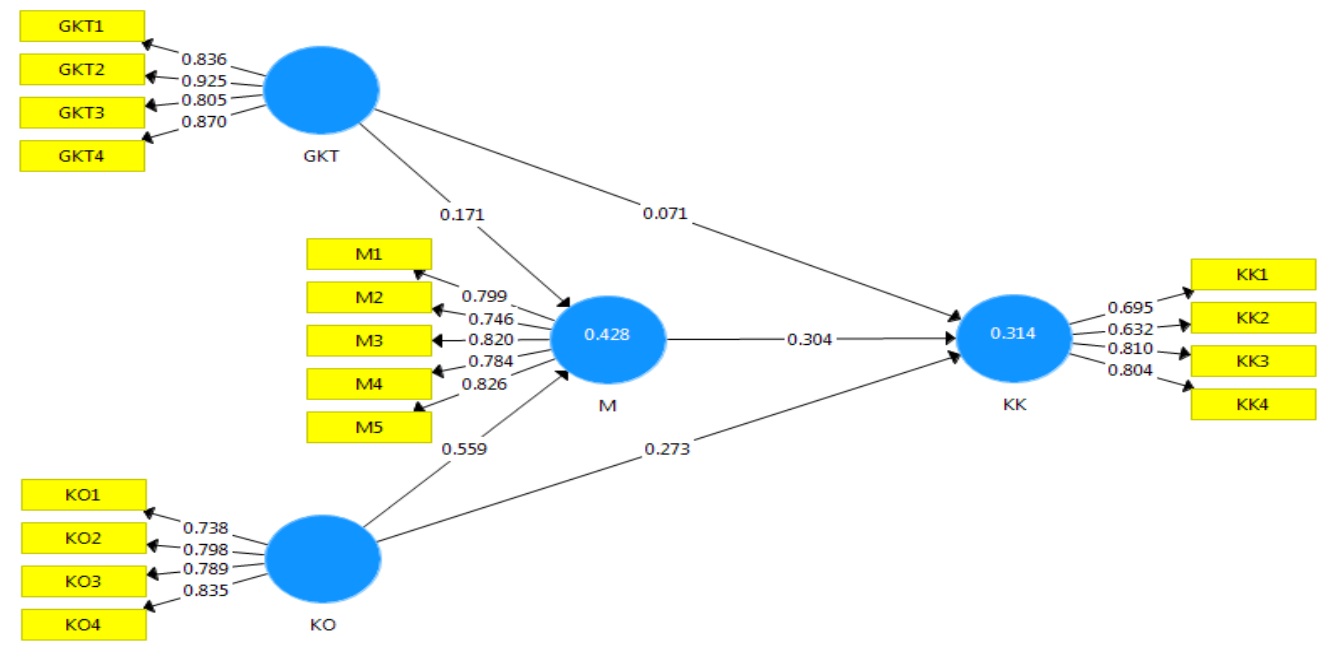

Gambar 1. Full Model Penelitian

Uji validitas \& Reabilitas

Tabel 1. Hasil Uji Validitas \& Reliabilitas

\begin{tabular}{ccccc}
\hline Variabel & Indikator & Hasil Uji & Keterangan & $\begin{array}{c}\text { Composite } \\
\text { Reliability }\end{array}$ \\
\hline Gaya Kepemimpinan & X1.1 & 0,836 & Valid & 0,919 \\
Transformasional & X1.2 & 0,925 & Valid & \\
& X1.3 & 0,805 & Valid & \\
Kompensasi & X2.1 & 0,870 & Valid & \\
& X2.2 & 0,738 & Valid & 0,869 \\
& X2.3 & 0,798 & Valid & \\
& X2.4 & 0,835 & Valid & \\
& & & & \\
& Valid & \\
Variabel & Indikator & Hasil Uji & Keterangan & Composite \\
& & & & Reliability \\
\hline Motivasi & X3.1 & 0,799 & Valid & 0,896 \\
& X3.2 & 0,746 & Valid & \\
& X3.3 & 0,820 & Valid & \\
& X2.4 & 0,784 & Valid & \\
& X2.5 & 0,826 & Valid & \\
\hline Kinerja Karyawan & Y.1 & 0,695 & Valid & 0,827 \\
& Y.2 & 0,632 & Valid & \\
& Y.3 & 0,810 & Valid & \\
& Y.4 & 0,804 & Valid &
\end{tabular}

Sumber: data primer, diolah tahun 2016 
Pengaruh Gaya Kepemimpinan...( Wahyu Budi Priyanto )

Tabel 2. Hasil Average Varience Extracted (AVE)

Variabel

AVE

Gaya Kepemimpinan Transformasional

0,740

(X1)

Kompensasi (X2)

0,546

Motivasi (X3)

0,625

Kinerja Karyawan (Y)

0,632

Sumber: data primer, diolah tahun 2016

Tabel.3 Hasil $R$-Square

\section{Pengaruh}

GKT, KO, M $\rightarrow$ K.Karyawan
R-Square

0,428

Sumber: data primer, diolah tahun 2016

Tabel 4. Uji Hipotesis (Result For Inner Weights)

\begin{tabular}{|c|c|c|c|c|c|}
\hline & $\begin{array}{l}\text { Original } \\
\text { Sample } \\
\text { (O) }\end{array}$ & $\begin{array}{l}\text { Sample } \\
\text { Mean } \\
(\mathrm{M})\end{array}$ & $\begin{array}{l}\text { Standard } \\
\text { Error } \\
\text { (STERR) }\end{array}$ & $\begin{array}{l}\text { T Statistics } \\
(|\mathrm{O} / \mathrm{STERR}|)\end{array}$ & $\begin{array}{c}\mathrm{P} \\
\text { Value }\end{array}$ \\
\hline $\begin{array}{c}\text { Gaya Kepemimpinan } \\
\text { Transformasional } \rightarrow \text { Kinerja } \\
\text { Karyawan }\end{array}$ & 0,071 & 0,072 & 0,085 & 0,832 & 0,406 \\
\hline $\begin{array}{c}\text { Kompensasi } \rightarrow \text { Kinerja } \\
\text { karyawan }\end{array}$ & 0,273 & 0,281 & 0,120 & 2,272 & 0,023 \\
\hline $\begin{array}{c}\text { Gaya Kepemimpinan } \\
\text { Transformasional } \rightarrow \text { Motivasi }\end{array}$ & 0,171 & 0,177 & 0,101 & 1,695 & 0,090 \\
\hline Kompensasi $\rightarrow$ Motivasi & 0,559 & 0,564 & 0,088 & 6,349 & 6,232 \\
\hline $\begin{array}{l}\text { Motivasi } \rightarrow \text { Kinerja } \\
\text { Karyawan }\end{array}$ & 0,304 & 0,309 & 0,107 & 2,832 & 0,005 \\
\hline $\begin{array}{c}\text { Gaya Kepemimpinan } \\
\text { Transformasional } \rightarrow \\
\text { Motivasi } \rightarrow \text { Kinerja } \\
\text { Karyawan }\end{array}$ & $\begin{array}{l}\mathrm{GKT} \\
\rightarrow \mathrm{M}= \\
0,171\end{array}$ & $\underset{0,304}{\stackrel{\mathrm{MO}}{\rightarrow}}$ & 0,034 & 1,505 & 0,1322 \\
\hline $\begin{array}{l}\text { Kompensasi } \rightarrow \\
\text { Motivasi } \rightarrow \text { Kinerja } \\
\text { Karyawan }\end{array}$ & $\begin{array}{c}\mathrm{KO} \rightarrow \mathrm{M}= \\
0,599\end{array}$ & $\begin{array}{c}\mathrm{M} \rightarrow \mathrm{KK}= \\
0,304\end{array}$ & 0,066 & 2,568 & 0,0102 \\
\hline
\end{tabular}

Sumber: data primer, diolah tahun 2016 
Kepemimpinan Transformasional, Kompensasi dan Motivasi sebesar 42,8\% dan sisanya sebesar $57,2 \%$ dijelaskan oleh variabel lain di luar penelitian. Dalam penelitian ini, model struktural yang digunakan tergolong moderat.

Pada penelitian ini, hasil analisis menunjukkan gaya kepemimpinan transformasional berpengaruh positif tetapi tidaksignifikan terhadap kinerja karyawan di PT. Bo Kyung Pasuruan. Hal ini dapat dimaknai bahwa di PT. Bo Kyung gaya kepemimpinan transformasional sudah dijalankan dan diakui keberadaannya, tetapi belum mampu untuk memberi dampak positif terhadap kinerja karyawan.

Hasil penelitian ini tidak mendukung dengan hasil penelitian terdahulu yang dilakukan oleh (Mondiani, 2012), (Paracha et al., 2012) dan (Pradeep and Prabhu, 2011) yang menyatakan bahwa gaya kepemimpinan transformasional berpengaruh positif dan signifikan terhadap kinerja karyawan.

Pada penelitian ini, hasil analisis menunjukkan bahwa kompensasi berpengaruh positif dan signifikan terhadap Kinerja Karyawan di PT. Bo Kyung Pasuruan. Hal ini dapat dimaknai bahwa semakin tinggi kompensasi yang diberikan maka akan meningkatkan kinerja karyawan. Adapun pengaruh keadilan kompensasi terhadap kinerja karyawan memberikan gambaran bahwa keadilan kompensasi merupakan hal penting yang harus diperhatikan oleh perusahaan sebagai upaya peningkatan semangat dan kepuasan kerja karyawannya.

Apabila karyawan memperoleh kepuasan dalam bekerja maka kinerja mereka akan cenderung meningkat dan karyawan akan semakin terdorong untukbekerja dengan lebih baik dalam mencapai tujuan perusahaan. Variabel pemberian THR memiliki pengaruh paling dominan, hal ini mengindikasikan bahwa perusahaan telah memberikan THR dengan memuaskan, baik dari sisi nominal maupun waktu pemberian THR. Dengan demikian, maka hasil penelitian ini mendukung hasil penelitian terdahulu yang dilakukan oleh (Odunlami and Matthew, 2014), (Ramzan et al., 2014), (Mondiani, 2012) dan (Endrianingsih, 2014) yang menyatakan bahwa kompensasi berpengaruh positif dan signifikan terhadap kinerja karyawan.

Pada penelitian ini, hasil analisis menunjukkan bahwa gaya kepemimpinan transformasional berpengaruh positif namun tidak signifikan, hal ini dapat dimaknai bahwa ada korelasi antara gaya kepemimpinan transformasional dengan motivasi namun secara nyata gaya kepemimpinan transformasional belum mampu memberikan efek atau dampak yang kuat terhadap motivasi karyawan di PT. Bo Kyung Pasuruan. Hasil penelitian ini tidak sejalan dengan hasil penelitian terdahulu yang dilakukan oleh (Sundi, 2013a) yang menyatakan bahwa gaya kepemimpinan transformasional berpengaruh positif dan signifikan terhadap motivasi.

Pada penelitian ini, hasil analisis menunjukkan bahwa kompensasi berpengaruh positif dan signifikan terhadap Motivasi Karyawan di PT. Bo Kyung Pasuruan. Hal ini dapat dimaknai bahwa semakin tinggi kompensasi yang diberikan maka akan meningkatkan motivasi karyawan. Motivasi merupakan sesuatu yang timbul dari dalam diri seseorang untuk mencapai tujuan finansial kepada karyawan yang sering disebut insentif. Kemudian motivasi non finansial yaitu dorongan yang diwujudkan tidak dalam bentuk finansial, akan tetapi berupa hal-hal seperti pujian, penghargaan, pendekatan manusiawi dan lain sebagainya. Hasil penelitian ini mendukung hasil penelitian terdahulu yang dilakukan oleh (Patrick, 2014) dan (Supartha and Sudana, 2015) yang menyatakan bahwa kompensasi berpengaruh positif dan signifikan terhadap motivasi. 


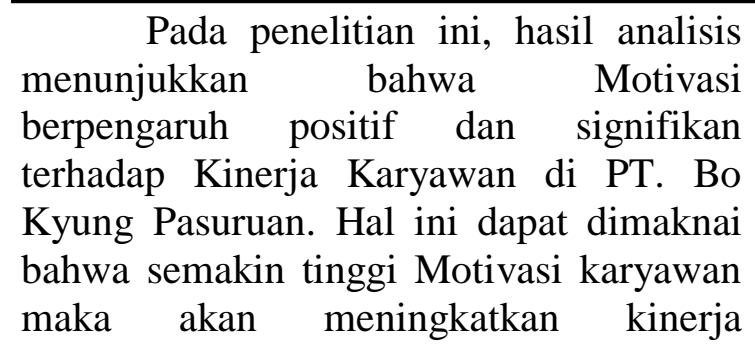
karyawan. Motivasi kerja merupakan proses sebagai langkah awal seseorang melakukan tindakan akibat kekurangan secara fisik dan psikis atau dengan kata lain adalah suatu dorongan yang ditunjukkan untuk memenuhi tujuan tertentu. Motivasi kerja adalah suatu kekuatan potensial yang ada didalam diri seseorang manusia, yang dapat dikembangkannya sendiri atau dikembangkan oleh sejumlah kekuatan luar, yang pada intinya berkisar sekitar imbalan moneter dan imbalan non moneter, yang dapat mempengaruhi hasil kinerjanya secara positif atau secara negatif, yang mana tergantung pada situasi dan kondisi yang dihadapi orang yang bersangkutan. Hasil penelitian ini mendukung hasil penelitian terdahulu yang dilakukan oleh (Masood, 2013a) dan (Endrianingsih, 2014) yang menyatakan bahwa motivasi berpengaruh positif dan signifikan terhadap kinerja karyawan.

Berdasarkan hasil analisis variabel
gaya kepemimpinan transformasional
berpengaruh positif dan signifikan
terhadap kinerja karyawan melalui
motivasi, dalam arti bahwa motivasi dapat
memediasi gaya kepemimpinan
transformasional terhadap kinerja
karyawan. Hasil penelitian ini
mengindikasikan bahwa pimpinan
memiliki kemampuan dalam memotivasi
dan mengawasi bawahannya untuk
mencapai standar kerja yang lebih baik
sebagai upaya mengantisipasi kegagalan
kerja yang mungkin terjadi. Karyawan
memiliki harapan bahwa seorang
pemimpin harus memiliki kemampuan
untuk menciptakan atau membangkitkan
semangat kerja bawahannya, mendorong
bawahannya untuk memiliki komitmen

yang kuat sebagai upaya pencapaian tujuan perusahaan. Hasil penelitian ini sejalan dengan hasil penelitian (Indra, 2015) yang menyatakan Gaya Kepemimpinan Transformasional berpenga-ruh tidak langsung terhadap kinerja karyawan melalui motivasi.

Dari hasil analisis dalam penelitian ini menunjukkan bahwa motivasi tidak dapat memediasi kompensasi terhadap kinerja karyawan. Hasil analisis menunjukkan variabel kompensasi berpengaruh positif namun tidak signifikan terhadap kinerja karyawan melalui motivasi. Kompensasi merupakan pertimbangan utama karyawan dalam melaksanakan pekerjaannya, kompensasi merupakan sumber kehidupan sehari-hari baik bagi karyawan maupun bagi keluarganya. Dengan demikian dalam bekerja karyawan akan cenderung mengharapkan penghasilan yang cukup untuk memenuhi kebutuhan hidup yang layak bagi seluruh keluarga karyawan yang bersangkutan. Dengan demikian, maka

kompensasi menjadi motivasi bagi karyawan dalam melaksanakan pekerjaanya secara sungguh-sungguh. Selain adil, kompensasi juga harus layak dalam hal nominalnya berdasarkan standar hidup yang layak dan peraturan ketenagakerjaan yang berlaku. Jika harapan karyawan atas kompensasi terpenuhi, maka akan tercipta kinerja yang lebih baik dengan perasaan puas dalam bekerja dan pada akhirnya dapat mencapai tujuan perusahaan secara keseluruhan. Hasil penelitian ini sejalan dengan hasil penelitian (Rini et al., 2014) dan Endrianingsih (2014) yang menyatakan kompensasi berpengaruh positif dan signifikan terhadap kinerja karyawan melalui motivasi.

\section{Penutup}

Berdasarkan hasil penelitian yang telah disampaikan, maka dapat disimpulkan sebagai berikut: Pertama, Gaya kepemimpinan transformasional 
berpe-ngaruh positif tapi tidak signifikan terhadap kinerja karyawan. Pada penelitian ini, hasil analisis menunjukkan gaya kepemimpinan transformasional berpengaruh positif tetapi tidak signifikan terhadap kinerja karyawan di PT. Bo Kyung Pasuruan. Hal ini dapat dimaknai bahwa di PT. Bo Kyung gaya kepemimpinan transformasional sudah dijalankan dan diakui keberadaannya, tetapi belum mampu untuk memberi dampak positif terhadap kinerja karyawan. Hasil penelitian ini tidak mendukung dengan hasil penelitian terdahulu yang yang menyatakan bahwa gaya kepemimpinan transformasional berpengaruh positif dan signifikan terhadap kinerja karyawan.

Kedua, Kompensasi berpengaruh positif dan signifikan terhadap kinerja karyawan. Pada penelitian ini, menunjukkan hasil analisis bahwa kompensasi berpengaruh positif dan signifikan terhadap Kinerja Karyawan di PT. Bo Kyung Pasuruan. Hal ini dapat dimaknai bahwa semakin tinggi kompensasi yang diberikan maka akan meningkatkan kinerja karyawan. Hasil penelitian ini sejalan dengan hasil-hasil penelitian sebelumnya.

Ketiga, Gaya kepemimpinan transformasional berpengaruh positif tapi tidak signifikan terhadap motivasi. Hasil analisis penelitian ini, menunjukkan bahwa gaya kepemimpinan transformasional berpengaruh positif namun tidak signifikan. Dimana hal ini dapat dimaknai bahwa ada korelasi antara gaya kepemimpinan transformasional dengan motivasi namun secara nyata gaya kepemimpinan transformasional belum mampu memberikan efek atau dampak yang kuat terhadap motivasi karyawan di PT. Bo Kyung Pasuruan. Hasil penelitian ini tidak sejalan dengan hasil penelitian terdahulu yang menyatakan bahwa gaya kepemimpinan transformasional berpengaruh positif dan signifikan terhadap motivasi.
Keempat, Kompensasi berpengaruh positif dan signifikan terhadap motivasi. Pada penelitian ini, hasil analisis menunjukkan bahwa kompensasi berpengaruh positif dan signifikan terhadap Motivasi Karyawan di PT. Bo Kyung Pasuruan. Hal ini dapat dimaknai bahwa semakin tinggi kompensasi yang diberikan maka akan meningkatkan motivasi karyawan. Hasil penelitian ini mendukung hasil penelitian terdahulu yang menyatakan bahwa kompensasi berpengaruh positif dan signifikan terhadap motivasi.

Kelima, Motivasi berpengaruh positif dan signifikan terhadap kinerja karyawan. Pada penelitian ini, hasil analisis menunjukkan bahwa Motivasi berpengaruh positif dan signifikan terhadap Kinerja Karyawan di PT. Bo Kyung Pasuruan. Hal ini dapat dimaknai bahwa semakin tinggi Motivasi karyawan maka akan meningkatkan kinerja karyawan. Hasil penelitian ini mendukung hasil penelitian terdahulu yang menyatakan bahwa motivasi berpengaruh positif dan signifikan terhadap kinerja karyawan.

Keenam, Motivasi memediasi pengaruh Gaya kepemimpinan transformasional terhadap kinerja karyawan. Dari hasil analisis dalam penelitian ini menunjukkan gaya kepemimpinan transformasional berpengaruh positif dan signifikan terhadap kinerja karyawan melalui motivasi, dalam arti bahwa motivasi dapat memediasi gaya kepemimpinan transformasional terhadap kinerja karyawan. Hasil penelitian ini sejalan dengan penelitian sebelumnya yang menyatakan Gaya Kepemimpinan Transformasional berpenga-ruh tidak langsung terhadap kinerja karyawan melalui motivasi.

Ketujuh, Motivasi tidak dapat memediasi pengaruh Kompensasi terhadap kinerja karyawan. Hasil penelitian ini menunjukkan bahwa motivasi tidak dapat memediasi kompensasi terhadap kinerja karyawan. Berdasarkan hasil analisis 
variabel kompensasi berpengaruh positif namun tidak signifikan terhadap kinerja karyawan melalui motivasi. Hal ini memberikan gambaran bahwa kompensasi merupakan hal penting yang harus diperhatikan oleh perusahaan sebagai upaya peningkatan semangat dan kepuasan kerja karyawannya. Namun, di PT. Bo Kyung karyawan sudah memahami situasi dan kondisi tingkat kompensasi yang dijalankan perusahaan. Dimana sudah tiga tahun berjalan PT. Bo Kyung melakukan penangguhan UMK secara resmi ke pemerintah. Kondisi ini yang menciptakan pandangan dari karyawan bahwa mereka sadar akan kemampuan perusahaan dalam memberikan kompensasi dalam bentuk upah/gaji kepada karyawan. Hasil penelitian ini tidak sejalan dengan hasil penelitian terdahulu yang menyatakan kompensasi berpengaruh positif dan signifikan terhadap kinerja karyawan melalui motivasi.

Adapun untuk penelitian selanjutnya, diharapkan mampu mengembangkan maupun memodifikasi model, agar dapat diperoleh hasil yang dapat menggambarkan peningkatkan kinerja karyawan dalam perusahaan.

\section{DAFTAR PUSTAKA}

Bass, B. M. \& Avolio, B. J. 1990. Developing Transformational Leadership; 1992 And Beyond. Journal Of European Industrial Training 14 (5).

Cooper \& Schindler, P. S. 2003. Business Research Methods ( $8^{\text {th }}$ Edition), New York, Mcgraw-Hill/Irwin.

Endrianingsih, D. A. 2014. Pengaruh Supervisi Kepala Sekolah, Kompensasi Dan Motivasi Kerja Terhadap Kinerja Guru Smk Negeri 1 Blitar. Universitas Muhammadiyah Malang.
Gomes \& Cardoso, F. 2000. Manajemen Sumber Daya Manusia, Jogjakarta, Andy Ofset.

Indra, K. 2015. Pengaruh Gaya Kepemimpinan Transformasional Terhadap Kinerja Karyawan Dengan Motivasi Kerja Sebagai Variabel Intervening (Studi Pada Karyawan Bank Jatim Cabang Malang). Jurnal Administrasi Bisnis (Jab), 01.

Masood, A. 2013a. Impact Of Motivation On Employee Performance With Effect Of Training Specific To Education Sector of Pakistan. International Journal of Scientific And Research Publication, 03.

Masood, A. 2013b. Impact Of Motivation On Employee Performance With Effect Of Training: Specific To Education Sector of Pakistan. International Journal of Scientific And Research Publications, 03.

Mondiani, J. 2012. Pengaruh Kepemimpinan Transformasional Dan Kompensasi Terhadap Kinerja Karyawan Pln (Persero) Upj Semarang Jurnal Administrasi Bisnis.

Muhammad, R., Kashif, Z. H. M., Ghazanfar, A. \& Arslan, A. M. 2014. Impact Of Compensation On Employee Performance (Empirical Evidence From Banking Sector Of Pakistan). International Journal of Business And Social Science, 5.

Odunlami, B. B. \& Matthew, A. O. 2014. Compensation Management And Employees Performance In The Manufacturing Sector, A Case Study Of A Reputable Organization In The Food And Beverage Industry. 2, (9):108-117. 
Paracha, M. U., Qamar, A., Mirza, A., Inam-Ul-Hassan \& ., H. W. 2012. Impact Of Leadership Style (Transformational \& Transactional Leadership) On Employee Performance \& Mediating Role Of Job Satisfaction" Study Of Private School (Educator) In Pakistan Global Journal of Management And Business Research, 12, (4):5564.

Patrick, M. K. 2014. The Effect Of Compensation On Employee Motivation: A Case Study of Chloride Exide. United States International University.

Pradeep, Devi, D. \& N.R.V., P. 2011. The Relationship Between Effective Leadership And Employee Performance. International Conference On Advancements In Information Technology With Workshop Of Icbmg 2011, 20, 1982017.

Pradeep, D. D. \& Prabhu, N. R. V. 2011. The Relationship Between Effective Leadership And Employee Performance International Conference On Advancements In Information Technology With Workshop Of Icbmg, 20, 198-207.

Ramzan, M., Zubair, H. M. K., Ali, G. \& Arslan, M. 2014. Impact Of Compensation On Employee Performance (Empirical Evidence From Banking Sector Of Pakistan). International Journal of Business And Social Science, 5.

Rini, Dibyantoro \& Ardianto, M. I. 2014. Pengaruh Kompensasi Terhadap Kinerja Karyawan Melalui Motivasi Kerja Sebagai Variabel Intervening (Studi Pada Karyawan Pt Duta Oktan Semesta Palembang). Jurusan Administrasi Bisnis Politeknik Negeri Sriwijaya.
Robbins, S. P. \& Judge, T. A. 2015. Perilaku Organisasi, Jakarta, Salemba Empat.

Siagian, S. P. 2004. Teori Motivasi Dan Implementasinya, Jakarta, Pt. Rinek Cipta.

Suartama, M. M. \& Ardana, K. 2014. Analisis Faktor-Faktor Yang Menentukan Kinerja Karyawan Di Pt. Arta Boga Cemerlang Denpasar. 1259-1271.

Sundi, K. 2013a. Effect Of Transformational Leadership And Transactional Leadership On Employee Performance Of Konawa Education Department At Southeast Sulawesi Province. International Journal of Bussines And Manajemen Invention, 02.

Sundi, K. 2013b. Effect Of Transformational Leadership And Transactional Leadership On Employee Performance Of Konawe Education Department At Southeast Sulawesi Province. International Journal of Business And Management Invention, 02.

Supartha, W. G. \& Sudana, W. 2015. Pengaruh Kompensasi Dan Lingkungan Kerja Fisik Terhadap Motivasi Dan Kepuasan Kerja Karyawan Di Grand Puncak Sari Restaurant Kintamani. Jurnal Manajemen Unud, 04. 